DOI: $10.2478 / \mathrm{v} 10122-009-0010-1$

\title{
LUSITANIAN PERSONAL NAMES WITH THE EQUINE MOTIVATION
}

\author{
KRZYSZTOF TOMASZ WITCZAK
}

\begin{abstract}
Krzysztof Tomasz Witczak. Lusitanian Personal Names with the Equine Motivation. Lingua Posnaniensis, vol. LI/2009. The Poznań Society for the Advancement of the Arts and Sciences. PL ISSN 0079-4740, ISBN 978-83-7654-080-1, pp. 155-163

The aim of this article is to find an equine motivation for several personal names attested in the territory of the Roman Lusitania. New or better Indo-European reconstructions (e.g. *melyos and *ku-melyos 'horse; stallion'; IE. *kankilos and *kankanos 'horse', as well as the root *kank-) in reference to the animal terminology are suggested. The distribution of the reflexes of IE. *ekwos 'horse' and *kankilos / *kankanos 'id.' in the area of the Hispanic Peninsula is carefully explained. Finally it is concluded that the horse and bull were the most esteemed animals in the culture of the ancient Lusitanians.
\end{abstract}

Krzysztof Tomasz Witczak, Department of Linguistics and Indo-European Studies, Philological Faculty, University of Łódź, ul. Lipowa 81, PL - 90-568 Łódź

Two important publications devoted to remains of the Lusitanian language appeared in 2005. The first one contains studies in the language and religion of the ancient Lusitania, dealing with, though not exclusively, interpretation of the preserved Lusitanian inscriptions and reconstructing the Lusitanian phonology and vocabulary (WiTcZAK 2005). The second is a monumental elaboration of the ancient anthroponymy registered in the Lusitanian area with numerous references to the onomastics of the adjacent regions of the Hispanic Peninsula (VALlejo Ruiz 2005). Though both works seem to refer to different problems, there are several common points, connected especially with the relation of the attested proper names from Lusitania to the preserved or suggested Lusitanian appellatives.

In my paper I intend to review one main question which concerns the Lusitanian personal names (PNs) derived from the Lusitanian names for animals. In most anthroponymic systems typical of Indo-European languages there is a considerable group of personal names, which are identical with animal names (e.g. Latin PN Titus = titus 'pidgeon', Greek PN $\Lambda$ $\kappa_{\kappa} \varsigma$, orig. 'wolf', Skt. PN Pedú- = Avest. pazdu- 'a kind of noxious insect' (cf. WACKERnAgel \& Debrunner 1954: 474), OPol. PN Dzik, orig. 'boar', OIr. PN Luch fem., orig. 'mouse') or derive in some way from the animal names (e.g. Latin PN Petronius < petro, -ōnis 'ram', Gk. PN $\Lambda \varepsilon \omega v i ́ \delta \alpha \varsigma<\lambda \varepsilon \varepsilon \omega v$ 'lion', Skt. PN Śunaka- < śvā, gen. sg. śunah 'dog') or represent some compounds containing an animal appellative (e.g. Gk. PN 'I $\pi \pi$ oкро́ $\tau \eta \varsigma<<$ i $\pi \pi \mathrm{o}$ 'horse'; OIr. PN Oscar < oss 'stag'; Avestan PN Zaratuštra- < uštra- 'camel'; German PN Adolf < Germanic *wulfaz 'wolf'). The personal names containing an appellative 
for 'horse' were especially popular, as the horse occupied a high position in the culture and beliefs of the Indo-Europeans. Also the Lusitanians were renowned for their love of the horses, thus a priori we hope of find a number of personal names which are related to the "horse" terminology. Also different animal derivations will be mentioned in my paper.

It should be emphasized that Vallejo Ruiz indicates animal connotations of some Lusitanian anthroponyms, e.g. he associates correctly the onomastic base BOU-, embracing such personal names as Bouius, Bouia, Bouana, Bouanna, Bouiani, Bouati, Boualus, Buanus (VAllejo Ruiz 2005: 214-216), with IE. *gwou- 'buey, vaca / ox, cow', cf. Old Irish bo 'id.', Sanskrit gauh m. f. 'ox, cow', pl. 'cattle', Gk. ßov̂s m. f. 'ox, cow', Lat. bos, E. cow.

In another place VALLEJo Ruiz (2005: 424-426) stresses that the anthroponym Taurus and its two variants (Taurilius, Taurocus) may be connected not only with Latin taurus 'bull', but also with the Lusitanian appellative TAUROM (acc. sg.) 'id.', registered in the famous Lusitanian inscription from Cabeço das Fráguas (WITCZAK 2005: 100-101; BLAžEK 2006: 12). It is a correct conclusion, especially as Taurocus cannot be explained with the aid of the well known Latin word-formation. The derivation from the Celtic lexical stock is completely excluded, as the Common Celtic name for 'bull' was *tarwos (cf. OIr. tarb, Welsh tarw, Gaulish tarvos 'id.').

Under the heading MATU- VAllejo Ruiz (2005: 351-354) gives derivation from Old Irish math ( $u$-stem) 'bear' (the exact meaning is, however, uncertain) ${ }^{1}$ as one of the possibilities of interpretating the compound personal names such as Matucenus, Matugenus. He notes the name Leoni (gen. sg.), presumably from Lat. leon or Gk. $\lambda \dot{\varepsilon} \omega v$ 'lion', among the personal names of uncertain attestation or doubtful origin. Thus in many cases Vallejo Ruiz gives clear information on "animal" etymologies of several personal names from Lusitania. Unfortunately, in some cases he was unable to indicate or correctly analyze these Lusitanian anthroponyms of similar origin, which I will discuss below.

\section{LUSITANIAN PN Cumelius.}

According to J. M. Vallejo Ruiz (2005: 298), this anthroponym is well attested in Lusitania, but appears also in Gallaecia, whereas a simple attestation from ancient Asturia remains ambiguous ("Este radical se documenta sobre todo en Lusitania, y tiene algunas extensiones hacia el norte, a territorio de galaicos; en la inscripción de Astorga tenemos un bracarense, por lo que la distribución por zona astur quizá sea casual"). He adds that "La formación Cumelius no tiene paralelos fuera de Hispania". I believe, however, that

${ }^{1}$ Note, however, that the related forms in Bryttonic Celtic denote 'fox', cf. Welsh madog 'fox', madyn 'id.', but maden 'a little she-fox, a vixen'. What is more, in the glossary by Hesychios of Alexandria $\left(5^{\text {th }}\right.$ or $6^{\text {th }}$ century

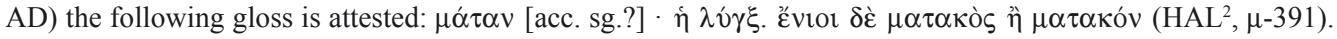
It is obvious that the Hesychian gloss in question cannot be dissociated from the Celtic words, especially in the situation when the form $\mu \alpha \tau \alpha \kappa o ́ \varsigma$ 'lynx' corresponds exactly to Welsh madog 'fox' (< Bryttonic *matākos). I am inclined to believe that Hesychios (or his source) registered here three Continental Celtic forms, perhaps used by the Galatians, who settled in Asia Minor, or alternatively by the Gaulish population, which inhabited the territory nearby the Greek colony Massilia (now Marseille). The semantic difference, observed in this case: 'bear?' (in Goidelic Celtic), 'fox' (in Bryttonic Celtic) and 'lynx' (probably in Continental Celtic), is noteworthy and needs an explanation. The Celtic root *mat- denoted in any case 'a kind of predator' ('bear or fox or lynx'). 
the exact equivalent appears in the East Baltic languages: Lith. kumelỹs m. 'stallion', also 'foal, colt', and Latv. kumelšs m. 'foal, colt' (< Baltic *kumelias). It represents an old IndoEuropean form $* k^{(w)} u$-melios ('what a stallion! what a foal!'). ${ }^{2}$ The basic term *melyos (m.) 'horse, stalllion' (not registered by POKORNY 1959) is perfectly preserved in two peripheries of the Indo-European world, namely in Celtic (cf. Old Irish meile m. 'horse, stallion, gelding' < Celtic *melyos) and Indo-Aryan (cf. OInd. máryah m. 'stallion'; Shumashti mair 'male ibex' < IA. *marya- < IE. *melyos). The prefix $* k u$ - (or perhaps $* k^{w} u$-) appears in most Indo-European languages, but shows a high productivity in Indo-Iranian, where it presents usually a pejorative or augmentative meaning. ${ }^{3}$ The prefix in question is frequent in the animal terminology, cf. Vedic kugo- m. 'miserable or weak bull' (RV 6.112, 6) vs. gó-, gaú- m. f. 'ox, cow', pl. 'cattle' < IE. * $g^{w}$ ou-, cf. Gk. ßov̂ऽ m. f. 'ox, cow', Lat. bos, E. cow. ${ }^{4}$ The Lusitanian personal name Cumelius, written in a latinized form, seems to represent IE. $* k u$-melyos. The predilection of the ancient Lusitanians for horse is well known (note the Lusitanian story about the west wind impregnating the mares, see e.g. BERMEJo BARRERA 1976: 301-310; 1982 [1994]: 83-91), thus the anthroponym Cumelius ('stallion') agrees with the well known character of the ancient people.

\section{LUSITANIAN PN Ic(c)onius}

VALlejo Ruiz (2005: 492) quotes two anthroponyms from the Hispanic Peninsula (one of them from the Lusitanian area). He refers to a number of anthroponyms collected by HoLDER (1904 [1962]: 17), which begin with the root *icc-, namely Iccauos, Iccalus, Iccianus, stressing that PALOMAR LAPESA (1957) did not register this anthroponym in his monograph of the Lusitanian personal names. Unfortunately, Vallejo Ruiz ignores the important fact that these two personal names derive evidently from the name of the Lusitanian horsegoddess Iccona, which is attested in the rock inscription from Cabeço das Fráguas (cf. BEST 1982: 65; MagGi 1983: 58-60; Tovar 1985: 254; PróSPER 2002: 53; WitcZAK 2005: 92-95;

2 As regards the etymology of the Baltic terms, see StalmaszczyK, WitcZaK $(2001 ; 2002: 73-74)$.

3 E.g. [1] OInd. ku-cela- n. 'a wretched garment' vs. cela- n. 'clothes, garment'; [2] OInd. ku-kāvya- m. 'a bad poem' vs. kāvya- n. 'poem, inspiration, wisdom'; [3] OInd. ku-plava- m. 'unsafe boat' vs. plavá- m. 'boat, skiff'; [4] OInd. ku-putra- m. 'bad son' vs. putrá- m. 'son, child'. There are also variants $k a-, k \bar{a}-$ and $k$-. The Lusitanian term COMAIAM (acc. sg.), denoting an animal sacrificed for the horse-goddess Iccona and meaning perhaps 'mare', may contain the prefix ko- (= OInd. $k a-)$, if the basic part -maia coresponds to OInd. máya- m. 'horse' (also 'camel' and 'mule') and máyı̄ f. 'mare' (WITCZAK 2005: 331). A different etymology of COMAIAM is possible as well.

${ }^{4}$ Other examples: [1] OInd. kutittiri- m. 'species of bird resembling the partridge' vs. tittíri- m. 'partridge'; [2] OInd. kuvaya- m. 'a particular kind of bird' vs. vaya- m. 'bird'; [3] Shughni xürn f. 'crow', Khufi, Roshani, Bartangi xürn, Sarikoli xern, Yazghulami $x^{w}$ orn 'id.' < Iran. *ku-warinā- or *ku-waranā- 'crow' (MoRGENSTIERNE 1974: 98), cf. Nepali ku-paykhi 'crow', Lith. kóvarnis 'raven’ vs. Lith. várna f. 'crow', Slavic *kavornz m. 'rook' vs. *vorna f. 'crow'; [4] Yazghulami kawō̌ 'leopard' < Iran. *ku-wastra- 'what a mouth!' or 'bad mouth' (Morgenstierne 1974: 42), cf. Av. vastra- 'mouth'; [5] OInd. kurara-, also kurala- m. 'a bad sea-bird; osprey' $<* k u$-laros (orig. 'what a sea-bird!') vs. IE. *laros m. (o-stem) 'a kind of sea-bird', cf. Gk. $\lambda \alpha \rho_{\rho} o \varsigma$ m. 'a ravenous sea-bird', perhaps 'sea-mew, gull', Scottish-Gaelic learg 'diver bird'. The Indo-European name in question derives from the onomatopeic and echoic root *lā-/*la- (PoKORNy 1959: 650-651). An analogous derivation can be suggested for Boeotian $\pi v \kappa \tau$ i $\varsigma$ (Arist., Ach. 879) 'an unknown animal, probably belonging to the Mustelidae

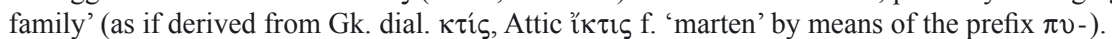


BLAžEK 2006: 12). This theonym is an exact equivalent of the Gaulish goddess Epona, whose connections with horses are confirmed by numerous inscriptions, literary sources and her representations in the Gaulish and Roman art. Both theonyms derive from the same archetype (IE. dial.) *Ekwona, which is perfectly motivated by the Indo-European term for 'horse', IE. *ekwos, cf. Lat. equus, OInd. aśva-, Avestan aspa-, Toch. B yakwe, Greek " $\pi \pi \mathrm{s}$, OIr. ech, Gaulish epo- 'horse'. It is clear that the Lusitanian name for 'horse' was *iccos, cf. also Greek Doric íkкоร m. 'horse'. I think that the ancient Belgians used the same term $\left(*_{i c c o s}\right)$, as it may be assumed from the name of the Belgian leader Iccius, who was a faithful ally of C. Iulius Caesar during his conquest of Gaul (HoLDER 1904 [1962]: 18), and from the theonym Icciona registered in Gallia Belgica (HAMP 1991). It is worth emphasizing that the Belgian personal name Iccius corresponds exactly with the Oscan PN Epius (liter. 'belonging to the horses; connected with the horses; horse-man'). Also the proper names beginning with Icc-, found in Gallia (Belgica), are of Belgian origin ${ }^{5}$ and they cannot be included to the thesaurus of the Gaulish and Celtic personal names. However, the similarity of the personal name Iccalus to the Brittonic terms for 'colt' (MW. ebawl, W. ebol, OCorn. ebol, Bret. ebeul < Brittonic Celtic *epālos) is noteworthy, as well as to the personal name Equalius (of Celtiberian origin) and place name Equalakos in Celtiberia. The Lusitanian PN Icconius, though contains the Lusitanian term for 'horse' (*icco-), derives from the name of the Lusitanian goddess Iccona and belongs in fact to the so called theophoric anthroponymy, as well as Eponeilos ( $<$ Epona, the Gaulish horse-goddess) or Reucalius ( $<$ Reue [dat. sg.], the main sky-god of the Lusitanian pantheon ${ }^{6}$ ). The theophoric character of these Lusitanian anthroponyms was not perceived by Vallejo Ruiz.

\section{LUSITANIAN PN Equaesus AND Equalius}

The former personal name is twice attested in Lusitania, three times in Celtiberia. The latter is registered in an inscription from Robredillo de Trujillo (CC), thus in the periphery of the Lusitanian area (VALLEjo Ruiz 2005: 320-322). Vallejo Ruiz correctly says that the anthroponym Equaesus is "de origen étnico" and was created from Equaesi, the tribe which lived in Asturia (Pliny, Nat. Hist. III 28). Thus name Equaesus demonstrates an Asturian (perhaps $q u$-Celtic) form, which derives from IE. *ek̂wos 'horse'. The native Asturian name for 'horse' (*equos) is also attested in an inscription found in La Vid (Pola de Gordón,

5 The Belgians were a Indo-European people, which used a different language than the Gauls, as correctly stated by C. Iulius Caesar (Commentarii de bello Gallico, I 1): Gallia est omnis divisa in partes tres, quarum unam incolunt Belgae, aliam Aquitani, tertiam qui ipsorum lingua Celtae, nostra Galli appellantur. hi omnes lingua, institutis, legibus inter se differunt. Gallos ab Aquitanis Garunna flumen, a Belgis Matrona et Sequana dividit. Most researchers ignore this first-hand information, which is confirmed by the onomastic data (the language of the Belgians preserved IE. * $p$, thus it is certain that it cannot belong originally to the Celtic language world).

${ }^{6}$ See especially Olivares Pedreño (2002: 169-186), Witczak (1999: 70-71; 2005: 101-104), MańczaK (2006: 63-65). Some researchers wrongly suggest an aquatic character of the god Reue, which was evidently the chief of the Lusitanian pantheon. To the best knowledge of mine, the aquatic beings belong to the secondclass deities in all known religions of the Indo-European tribes. It is easier to derive Reu-e (dat. sg.) from the Indo-European name of the main sky-god, IE. *Dyēus, as I suggested earlier (WITCZAK 1999: 70-71; 2001; 2005: 101-104). 
León): DEIS EQUEUNUB(O). According to prof. I. R. DANKA (personal com.), the byname (in dat. pl.) EQEUNUB $(O)$ refers to the divine twins and means exactly 'to the sons [riding] on the horse' (< IE. *ekwei-sünu-bhos). This interpretation is accepted by some researchers (WITCZAK 2005: 274; BLAŽEK 2006: 12).

The personal name Equalius derives evidently from Common Celtic *ekwālos 'foal, colt' (cf. MW. ebawl, OCorn. ebol, Bret. ebeul 'id.'). It seems to be of Celtiberian origin, cf. the place-name Equalakos in Celtiberia (JóRDAN Cólera 2004: 194). Thus Equalius cannot belong to the native Lusitanian anthroponymy.

\section{LUSITANIAN PN Eponeilus, EPARUS AND EPEICUS}

ValLejo Ruiz (2005: 321-322) connects these three personal names with the term for 'horse', IE. *ekwos, indicating that the change of *kw to $p$ is well attested in one group of the Celtic languages, as well as in some Italic dialects (e.g. Oscan and Umbrian). Only one of these three anthroponyms, namely Epo[n]eilos, is registered in the territory of Lusitania. The name in question derives probably from the Gaulish theonym Epona (= Lusitanian Iccona, Belgian Icciona), thus we cannot include it to the native Lusitanian onomastics. The same must be concluded about the personal names Eparus and Epeicus, which are registered out of Lusitania. They may belong to the anthroponymy of Celtici, which inhabited both Gallaecia Bracarensis (whence Epeicus) and Meseta (whence Eparus).

\section{LUSITANIAN PN Cancilus, Cancilius.}

Vallejo Ruiz (2005: 257) registers five personal names in question in the area of the ancient Lusitania, two anthroponyms (both written as Cangilus with an effect of the lenition) in Asturia. He refers to Palomar Lapesa (1957: 58) and Albertos Firmat (1966: 74), who derived these proper names from the Indo-European root *kāk-, *k̂kzk- 'saltar, brotar, moverse con fuerza / springen, hervorsprudeln, kräftig sich tummeln' (PoKORNy 1959: 522-523). This explanation is generally correct, but the nasal infix suggests the straightforward derivation from the nasal variant *kank-, which appears in four (or perhaps even seven) subgroups of the Indo-European family, namely in:

INDIC: Sanskrit kiñkirah (m.) 'horse, foal' (cf. Monier-WiLliams 1899: 282; KočERGinA 1987: 162). It comes back to IE. *kank-ilos m. 'horse'.

BaLTic: Latv. kankans (m.) 'ein schlechtes Pferd', kankâns (m.) 'ein grosses, mageres Pferd' (Mülendach 1929-1932: II 155, 156; Sabaliauskas 1968: 161). Both derive from IE. *kank-ănos or *kank-ānos, respectively.

Germanic: ONord. Runic hanhai (dat. sg.) 'dem Renner', OIcel. Hā-, OHG. Hāh-, Hang- as the initial member of the Germanic antroponymes (< Gmc. *hánhaz); ON. hestr m. 'stallion, horse', Dan. hest, Norw. hest, Swed. häst (< Gmc. *hánhistaz); OE. hengest, OFris. hanxt, hengst, OFrank. chanzisto, chengisto, OHG. hengist, G. Hengst 'stallion' (< Gmc. *hangistáz). The Germanic terms derive from IE. *kank-os (o-stem) and *kankistos.

CELtic: Welsh caseg (f.) 'mare', Bret. cezeg (pl.) 'horses', dial. 'mares', OCorn. cassec 'mare' (< Bryt. *kassika $<$ Celt. *kank-stikā). The Celtic term for 'mare' appears also in 
Gaulish toponymy: Cassiciate (loc. sg.) 'Pferdepark' (PoкоRny 1959: 523). Also the Gaulish place name Canecosedlom (Autun) denotes perhaps 'a horse village', thus it refers to the village of horse-breeders.

anatolian: ?? Carian (gloss) kakkabe 'head of the horse'. According to Georgiev (1960: 611), it derives from IE. *kanko-bho- 'Hengst / stallion'. The suffix -bho- is a common element in the Indo-European animal terminology (cf. BRUGMANn 1970: 331), but the attribution of the gloss, as well as the etymology remains uncertain (BLAŽEK 1992: 50).

SLAVIC: ?? According to TRUBAČEv (1983: 197), the Slavic names for 'horse', like Pol. $k o n$, may belong to this bunch of words and derive from IE. *kank-yos by a progressive dissimilation $* k-* k>k-\varnothing$. This explanation is acceptable only, if the suggested dissimilation was performed before the Common Slavic palatalization of the gutturals. Trubačev suggests additionally that the Slavic form *konjb may be a back-formation from *konikb (cf. Pol. konik 'small horse'). In this case the development of *kankyukas > Slavic *konikb would be justified by the existence of three successive voiceless gutturals $(* k-* k-* k>k-\varnothing-k)$. Trubačev's etymology and derivation are hardly acceptable, but not impossible (cf. BLAŽEK 1992: 49-50).

? CANTABRIAN: Evidence for the Cantabrian name for 'horse' is taken from the tribal name Concani $\bar{l}$, which seems to be derived from the Indo-European root *kank-. This derivation is confirmed by Horace's statement (Carm. III 4, 34: laetum equino sanguine Concano), according to which Concani drink ritually the blood of the horses and represent "people of the horse" in the totemic sense ('Pferdeleute', according to SCHERER 1955: 209). In fact, Concani were renowned for their horse-breeding. It is possible, therefore, that Horace's name Concanus (sg. pro pl.) denoting 'horse-man' is the exact equivalent of Latv. kankans, kankâns (orig. 'horse', later 'ein schlechtes Pferd', 'ein grosses, mageres Pferd'). The comparison seems convincing, though the vowel [o] as a Cantabrian reflex of schwa (IE. *a) requires an explanation.

In his Indo-European etymological dictionary PoKORNY (1959: 522) quotes only the lexical evidence from Germanic and Celtic. He omits the valuable lexical data from the satom languages (Sanskrit, Latvian, perhaps also Slavic), which document an initial velar (IE. *k-). What is more, he reconstructs the palatal guttural stop (IE. $* \hat{k}$ ), referring to the Lithuanian verbs šókti 'springen, tanzen' and šankinti '(ein Pferd) springen machen', which may not be related to this bunch of words. I quote the full evidence for the root *kank- 'horse' to demonstrate the necessity of reconstructing the Indo-European root with the initial $* k$ (like in Sanskrit and Latvian) and with the schwa (ə), which is guaranteed by Sanskrit [i] and European [a] (cf. Balt. $a$, Celt. $a$, Germ. $a$, Anat. $a$, Lusit.-Astur. $a$ ). It is uncertain if the Cantabrian tribal name Concani, which appears to derive from the same "horse" motive (cf. especially Latv. kankans), gives a basis to reconstructing IE. $*_{3}$ (Note, that Greek and Phrygian have [o] as a regular reflex of this phoneme). The difference observed in the Lusitanian, Asturian and Cantabrian proper names suggests that the ancient Cantabrians had to use a different Indo-European language or dialect in comparison with the Lusitanians and the Asturians.

If the Lusitanian personal name Cancilus (=Asturian Cangilus) is directly related to the Sanskrit appellative kiñkirah (m.) 'horse, foal' (< IE. *kənkilos m. 'horse'), then the anthroponym in question belongs to the "horse" sphere. The second name Cancilius is, of course, a simple derivative from Cancilus (= Skt. kiñkirah). 


\section{ADDITIONAL REMARKS}

In my article I analyzed only these Lusitanian personal names, which derive from three different appellatives for 'horse'. However, I would like to indicate some new possibilities in interpreting the Lusitanian anthroponyms as possible derivatives from the animal terminology.

[1] The name for 'young animal', also 'foal, short horse' (cf. Gallo-Latin mandus 'a kind of short horse'; OIr. menn 'young of an animal', especially 'kid, calf, foal', W. myn 'young of an animal; kid, foal', MCorn. min (voc.), MBret. menn 'kid'; OPrus. maldian 'foal, colt' < IE *mandiyom by the dissimilation of the nasals: $\left.*_{n-} *_{m}>*_{n-} *_{n}>l-n\right)$ is perhaps registered in the personal name Mel-man(d)us (VAllejo Ruiz 2005: 360-361).

[2] The anthroponym Lapona and its variants (VALLEJo RuIz 2005: 325) seem to derive from IE. *lāpo- 'ox, cow' (also 'buffalo'), cf. Alb. lopë (f.) 'cow'; German dial. (in Switzerland) loobe, lioba f. 'cow' (< Gmc. *lōbō[n]-); Latv. luõps (m.) 'cattle' (PoKorny 1959: 652); OIr. láeg, lóig (m.) 'calf'; Welsh llo (pl. lloi), Corn. loch, Bret. leue 'calf' (< Insular Celtic *lā $[p] \operatorname{egos}(\mathrm{m}$.$) 'calf, bull calf'). With an expressive reduplication l u-$ : OInd. lulāpah̆ (m.) 'a buffalo', Late Sanskrit lulāya- (m.) 'id.' (Monier-Williams 1899: 905). It is uncertain whether Hitt. lahpaš 'ivory; elephant' belongs to this lexical bundle or not. PuHveL (2001: 12-13) lists the evidence, giving no etymology of the Hittite term in question.

[3] The personal name Pecuni(us) (Vallejo Ruiz 2005: 476) derives obviously from IE. *pek̂u- n. 'cattle', cf. Lat. pecus (u-stem) 'id.', Sanskrit paśu-, Gothic faíhu 'is.'. If it represents an autochtonic ingredient, and not a Latin nomen gentilicium, then we have to do with a Lusitanian term preserving initial $* p$ - as in the case of Lusit. PORCOM (acc. sg.) 'pig, piglet' .

[4] Cuna (Vallejo Ruiz 2005: 470), as well as Cuntius, Cuntinus, Cundigus (Vallejo RuIz 2005: 298-299), represents probably IE. *kwwōn (oblique stem *k̂ku-) 'dog', cf. OInd.

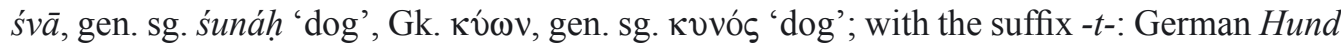
'dog'.

[5] The personal names Casap(us) and Casabius (VAllejo Ruiz 2005: 265) belong perhaps to the same group. In my opinion, they may be treated as the ancient renderings of a substratal term, which became a source form of the modern Ibero-Romance names for 'young rabbit', cf. Port. caçapo m., Sp. gazapo m., Catal. (in the west and central dialects) catxap 'id.'.

\section{CONCLUSIONS}

The above analysis of the non-Latin anthroponymy, attested in the territory of Lusitania, demonstrates a great and undeniable role of the domesticated animals in the life of the ancient Lusitanians, especially horses and cattle. There exist numerous native personal names which seem to derive from the appellatives for 'horse' (cf. Cancilus, Cancilius; Cumelius; Eponeilus; Equalius; Icconius; perhaps also Mel-mandus) and these for 'cattle' (cf. Bouius, Bouia, Bouana, Bouanna, Bouiani, Bouati, Boualus, Buanus; Lapona; Pecuni(us); Taurilius, Taurocus, Taurus < Lusit. taurom acc. sg. 'bull'). Though our knowledge about the Lusitanian vocabulary is limited, the parallel terms and names, attested 
in different Indo-European languages, give a possibility of interpreting the Lusitanian personal names as derived from the animal names.

It is worth emphasizing that the Lusitanian anthroponymy contained also personal names of foreign origin. Apart from a number of personal names derived from the Lusitanian names for 'horse' (e.g. Cancilus, Cancilius; Cumelius; Icconius) the anthroponymy attested in Lusitania contained personal names both of Gaulish origin (e.g. Eponeilus) and of Celtiberian one (e.g. Equalius). There are also personal names, which demonstrate an "ethnic" origin, though they finally derive from the zoological terminology (e.g. Equaesus).

\section{BIBLIOGRAPHY}

Albertos Firmat María Lourdes. 1966. La onomástica personal primitiva de Hispania: Tarraconense y Bética. Salamanca.

Bermejo Barrera José Carlos. 1976. "Los caballos y los vientos: Un mito lusitano antiguo.” Hispania Antiqua 6, 301-310.

Bermejo Barrera José Carlos. 1982 [1994]. Mitologia y mitos de la Hispania prerromana. Vol. 1. Madrid ( $2^{\text {nd }}$ edition, Madrid 1994).

BEST Jan G.P. 1982. "Zur frühindoeuropäischen Sprache in Lusitanien." TA AANTA. Proceedings of the Dutch Archaeological and Historical Society 13, 1981 (Supplementum epigraphicum mediterraneum, Middelie 1982), 63-68.

BLAŽEK Václav. 1992. Historická analýza indoevropské zoologické terminologie (savci). Brno.

BLAžEK Václav. 2006. "Lusitanian Language.” Sborník Praci filozofické Fakulty Brněnské Univerzity N. 11, $5-18$.

Brugmann Karl. 1970. Kurze vergleichende Grammatik der indogermanischen Sprachen. Berlin.

Campanile Enrico (ed.) 1983. Problemi di lingua e di cultura nel campo indoeuropeo. Pisa.

DE Hoz Javier (ed.) 1985. Actas del III Coloquio sobre lenguas y culturas paleohispanicas (Lisboa, 5-8 noviembre 1980), (Acta Salamanticensia, Filosofia y Letras no. 1962). Salamanca.

Georgiev Vladimir. 1960. "Der indoeuropäische Charakter der karischen Sprache.” Archív Orientální 36, 607619.

Hamp Eric P. 1991. "Incidence of Gaulish Divine Names in -on-”. Studia Celtica Japonica 4, 71-72.

Holder Alfred. 1904 [1962]. Alt-celtischer Sprachschatz. Vol. 2 (I-T). Leipzig. Reprinted in 1962 in Graz.

Jórdan Cólera Carlos. 2004. Celtibérico. (Monografías de Filología Griega 16). Zaragoza.

KoČERGInA Vera A. 1987. Sanskritsko-russkij slovar'[A Sanskrit-Russian dictionary]. Moskva.

KrAHE Hans (ed.). 1955. Corolla Linguistica. Festschrift Ferdinand Sommer zum 80. Geburtstag am 4. Mai 1955, dargebracht von Freuden, Schulern und Kollegen. Wiesbaden.

MagGi Daniele. 1983. "Sui teonimi Trebopala e Iccona nell'iscrizione lusitana del Cabeço das Fráguas." In: CAMPANile 1983: 53-60.

MańCZaK Witold. 2006. "Lusitanien Reve = Latin Iovi.” Lingua Posnaniensis 48, 63-65.

Marcinkiewicz Józef, Ostrowski Norbert (eds.). 2001. Munera Linguistica et Philologica Michaeli Hasiuk dedicata. Poznań.

Monier-Williams Monier. 1899. A Sanskrit-English Dictionary. Oxford.

Morgenstierne Georg. 1974. Etymological Vocabulary of the Shughni Group. Wiesbaden.

Mülenbach Karl. 1929-1932. Latviešu valodas vārdnīca [A Dictionary of the Latvian Language]. Vol. 1-4. Riga.

Olivares Pedreño Juan Carlos. 2002. Los dioses de la Hispania Celtica. (Bibliotheca Archaeologica Hispana 15). Madrid.

Palomar Lapesa María. 1957. La onomastica personal pre-latina de la antiqua Lusitania. Salamanca.

PoKorny Julius. 1959. Indogermanisches etymologisches Wörterbuch. Bern-München.

PrósPer Blanca María. 2002. Lenguas y religiones prerromanas del occidente de la Península Ibérica. (Acta Salmanticensia. Estudios Filológicos 295). Salamanca. 
Puhvel Jaan. 2001. Hittite Etymological Dictionary. Vol. 5: Words beginning with L. Berlin-New York.

SabaliausKas Algirdas. 1968. "Baltų kalbų naminių gyvulių pavadinimai (jų kilmè ir santykis su atitinkamais slavų kalbų pavadinimais)." Lietuviu kalbotyros klausimai 10, 101-190.

SCHERER Anton. 1955. "Die keltisch-germanischen Namengleichungen.” In: Krahe 1955: 199-210.

Stalmaszczyk Piotr, Witczak Krzysztof Tomasz. 2001. "On Two Balto-Celtic Terms for 'stallion'.” In: MarcinkieWICZ, OsTROWSKI 2001: 29-32.

Stalmaszczyk Piotr, Witczak Krzysztof Tomasz. 2002. "Etyma Celtica (1-3).” Studia Indogermanica Lodziensia $4,73-79$.

Tovar Antonio. 1985. "La inscripción de Cabeço das Fráguas y la lengua de los Lusitanos." In: DE Hoz 1985: 227-253.

TRUBAČEv Oleg N. (ed.) 1983. Ėtimologičeskij slovar'slavjanskikh jazykov. Vol. 10. Moskva.

Vallejo Ruiz José María. 2005. Antroponimia indígena de la Lusitania romana. Vitoria-Gasteiz.

Wackernagel Jakob, Debrunner Albert. 1954. Altindische Grammatik. B. II, 2: Die Nominalsuffixe. Göttingen.

WitczaK Krzysztof Tomasz. 1999. "On the Indo-European Origin of Two Lusitanian Theonyms (Laebo and Reve)." Emerita 67(1), 65-73.

WitczaK Krzysztof Tomasz. 2001. "Reve Gallaeco. A Contribution to the Worship of a Sky-God in the Ancient Gallaecia and Lusitania." Eos 88, 245-253.

WitczaK Krzysztof Tomasz. 2005. Język i religia Luzytanów. Studium historyczno-porównawcze [The Language and the Religion of the Ancient Lusitanians. A Historical-Comparative Study]. Łódź. 